\title{
DECEPTIVE IS EFFECTIVE NEGOTIATION STRATEGIES TO CUSTOMERS FOR USING CONDOMS CONSISTENTLY
}

\author{
Putu Sukma Megaputri ${ }^{1}$, Putu Kusuma Dewi Dian Prima ${ }^{1}$, Cindy Meilinda Sari ${ }^{1}$, I Dewa Ayu Rismayanti ${ }^{2}$
}

\begin{abstract}
The Consistency of condom use by the sex customers is very low. These problems occur due to the lack of negotiations carried out by the sex workers into their customers. This study aims to determine the most effective negotiation strategies for the customers to consistently using condoms. The study was conducted by using a survey crosssectional of sex workers directly with the sample of 100 peoples, which who selected by a random cluster sampling in Denpasar city. The data collected by interviews conducted by using a questionnaire about the characteristics and modification Condom Influence Strategy Questionnaire (CISQ) developed by Noar. The results of the study show that about $63 \%$ of customers consistently used condoms in the past week. The effective negotiation strategies used so that customers consistently using condoms is deceptive by sex workers to their client's variables associated with consistent condom use is the availability of condoms and sex worker's age. Deceptive is the most effective strategy to increase consistent condom use.
\end{abstract}

Keywords - Negotiations Condoms, Female Sex Workers, Consistency of Condom Use

\section{INTRODUCTION}

he incidence of HIV/AIDS by 2015 in some countries fell by $35 \%$ in terms of 2000 , but this does not seem in Indonesia. Global Report in 2014 also showed 1.2 million people have died from AIDS appears to have declined by $42 \%$ from 2005 resulting from the use of anti-retroviral (ARV). A total of 15.8 million people living with HIV/AIDS (PLHIV) has been accessed ARVs in 2015, an increase of 2014 was only (AOR: 2.5 95\% CI: 1.06 to 5.62). While other 13.6 million [1]. Board of the United Nations (UN) has declared that the HIV / AIDS will be addressed in 2030, as stated in the Sustainable Development Goals (SDGs) as one of the goals by reducing the incidence of HIV/AIDS and increasing the use of antiretroviral drugs for people living with HIV.

${ }^{1}$ D III Midwifery Program,STIKesBuleleng; 081547371522; megaputri_sukma@yahoo.com

dian_pkd@yahoo.com

${ }^{2}$ S1 Program Nursing Department, STIKesBuleleng; rismajegeg@gmail.com
The HIV/AIDS epidemic in Asia is still largely concentrated in risk populationst, and the majority of infection transmisson due to heterosexual activity [2]. The estimatin of direct female sex workers live in Indonesia is 124,996 person, while the estimation for indirect female sex workers is 104.860 people who living with HIV people is 591,823 [3]. Almost in the entire territory of Indonesia with a concentrated epidemic pattern, except the eastern part of Indonesia, especially in Papua with the pattern of the epidemic generalization. The Concentration epidemics also appear in Bali with an estimation is 3,378 direct sex workers, indirect sex workers and the 3,464 people living with HIV 26,000 (3). The Cases of HIV/AIDS in Bali in Denpasar with the highest percentage of HIV cases as much as $40.14 \%$ and the majority of cases are found in sex workers. One of the triggers for the increased incidence of HIV./.AIDS is a lack of awareness of condom use during sex to its customers.

The several studies indicated that the consistently of customers condom use was very low, the use of condoms only about 35\% [4], and 65\% in Denpasar (5). The low of percentage condom use due to limited of the condom supply by sex workers. In addition, the data from the research was reveal that the negotiation of condoms using by sex workers is also very low. This data derived from measurement of negotiation is only measured by a few questions without looking in depth the strategies practiced by sex workers. As one of the studies on methods for measuring condom negotiation was originally used in the United States with nine questions and only six questions were validated [6]. The method was adopted in Cambodia to measure condom negotiation conducted by WPS to their customers [7]. This research could be interesting to do with adapting the measurement strategy condom negotiation in Bali.

\section{METHODS}

This study is a survey research with an approach, crosssectional with a target population of direct sex workers and the affordable population is direct sex workers in 
the city of Denpasar in 2016. The total sample of 100 people chosen at random cluster sampling.Data collection was conducted through interviews where sex workers work, assisted by six enumerators and the use of questionnaires which have been tested previously. Questions about condom negotiation adoption of CISQ [6]. In this study of nine components CISQ only uses six components in accordance with the test results of questionnaires namely: withholding sex, direct request, seduction conceptualizing relationship, risk information, and deception. Measurement of negotiations was assessed using three questions on each component, then the measurement was assessed by comparing the cutoff results of total respondents of each component. The data were analyzed using univariate, bivariate with chi-square and multivariate logistic regression analysis using the software.

\section{RESULTS AND DISCUSSIONS}

Table 1. Frequency Distribution

\begin{tabular}{lc}
\hline \multicolumn{1}{c}{ Variable } & $\mathrm{f}(\%)$ \\
\hline Age (mean \pm SD) & $38 \pm 39.1$ \\
Length in the work (Mean \pm SD) & $25 \pm 36.1$ \\
Lengtu of work in the site (months) & $38 \pm 39.1$ \\
(mean \pm SD) & \\
Education & \\
Higher & $87(87 \%)$ \\
Low & $13(13 \%)$ \\
Perceived Susceptibility & $70(70 \%)$ \\
Good & $30(30 \%)$ \\
Intermediate & \\
Availability of condoms & $74(74 \%)$ \\
Always & $26(26 \%)$ \\
Rarely & \\
Negotiations & $70(71 \%)$ \\
Witholding sex & $76(76 \%)$ \\
Direct request & $55(55 \%)$ \\
Seduction & $53(53 \%)$ \\
Conceptualizing relationship & $76(76 \%)$ \\
Risk information & $57(57 \%)$ \\
Deception & \\
Condom Use & $63(63 \%)$ \\
Consistent & $27(27 \%)$ \\
No &
\end{tabular}

The average age of sex workers was 38 years old, with the average length of working as a sex worker is 25 months and the average length of work in the last location of the interview was 38 months. The most of the sex workers with higher education $87 \%$, with a good perception of $70 \%$. Most in the location provided condoms as much as $76 \%$. Negotiation strategies that most people do are the direct request and risk information (76\%). A proportion of consistent condom use during the last week by the customer as much as $63 \%$.

Table 2. Analysis of Bivariat

\begin{tabular}{|c|c|c|c|}
\hline \multirow{2}{*}{ Variables } & \multicolumn{2}{|c|}{$\begin{array}{c}\text { Used Condom } \\
\text { Consistenly }\end{array}$} & \multirow{2}{*}{$\mathrm{p}$ Value } \\
\hline & $\begin{array}{l}\text { Use } \\
(\%)\end{array}$ & $\begin{array}{l}\text { Not } \\
(\%)\end{array}$ & \\
\hline \multicolumn{4}{|l|}{ Age } \\
\hline Younger $(\leq 38$ years $)$ & 95.2 & 73.0 & 0.001 \\
\hline Tua (> 38 years) & 4.8 & 27.0 & \\
\hline \multicolumn{4}{|l|}{ Education } \\
\hline Higher & 55.6 & 45.9 & 0.3 \\
\hline Low & 44.4 & 54.1 & \\
\hline \multicolumn{4}{|l|}{ Knowledge of } \\
\hline Good & 90.5 & 81.1 & 0.18 \\
\hline Internediate & 9.5 & 18.9 & \\
\hline \multicolumn{4}{|l|}{ Perceived susceptibility } \\
\hline Good & 76.2 & 59.5 & 0.07 \\
\hline Intermediate & 23.8 & 40.5 & \\
\hline \multicolumn{4}{|l|}{ Condom availability } \\
\hline Always & 90.5 & 45.9 & $<0.0001$ \\
\hline Rarely & 9.5 & 54.1 & \\
\hline \multicolumn{4}{|l|}{ Negotiations } \\
\hline Yes & 69.8 & 37.8 & 0.002 \\
\hline No & 30.2 & 62.2 & \\
\hline
\end{tabular}

The result of Table 2 explained that the limit of pvalue could be incorporated into the multivariate analysis was 0.2 . Further, the variable could be entered into the multivariate analysis of ages, knowledge, perceivedsusceptibility, availability of condoms and condom negotiation.

The Table 3 explained about the analysis bivarat six valid strategy for negotiating condom. By looking at a $\mathrm{p}$ value limits, the strategy can be entered into the multivariate analysis with holding sex, direct request and deception. The multivariate analysis using logistic regression with the results of the most effective strategies to increase consistent condom use. Strategies to deceptive customers 2.5 times increase in the customers use condoms consistently. Other variables associated with consistent condom use are age and the availability of condoms 
Table 3. Bivariate Analysis Negotiation Strategies

\begin{tabular}{|c|c|c|c|}
\hline \multirow{2}{*}{ Variable } & \multicolumn{2}{|c|}{$\begin{array}{c}\text { Consistent condom } \\
\text { used }\end{array}$} & \multirow[t]{2}{*}{$\begin{array}{l}\mathrm{P}- \\
\text { Value }\end{array}$} \\
\hline & $\begin{array}{c}\text { Wear } \\
(\%)\end{array}$ & No $(\%)$ & \\
\hline \multicolumn{4}{|l|}{ Witholding Sex } \\
\hline Do & 76.2 & 62.2 & 0.14 \\
\hline None & 23.8 & 37.8 & \\
\hline \multicolumn{4}{|l|}{ Direct Request } \\
\hline Do & 82.5 & 64.9 & 0,046 \\
\hline None & 17.5 & 35.1 & \\
\hline \multicolumn{4}{|l|}{ Seduction } \\
\hline Do & 55.6 & 54.1 & 0.85 \\
\hline None & 44.4 & 45.9 & \\
\hline \multicolumn{4}{|l|}{ Conceptualizing } \\
\hline \multicolumn{4}{|l|}{ Relationship } \\
\hline Do & 55.6 & 48.6 & 0.5 \\
\hline None & 44.4 & 51.4 & \\
\hline \multicolumn{4}{|l|}{ Risk Information } \\
\hline Do & 79.4 & 70,3 & 0.3 \\
\hline None & 20.6 & 29.7 & \\
\hline \multicolumn{4}{|l|}{ Deception } \\
\hline Do & 65.1 & 43.2 & 0.03 \\
\hline None & 34.9 & 56.8 & \\
\hline
\end{tabular}

Table 4. Multivariate Analysis

\begin{tabular}{lllll}
\hline Variable & OR & P Value & \multicolumn{2}{c}{$95 \%$ CI } \\
\cline { 4 - 5 } & & & Lower & Upper \\
\hline $\begin{array}{l}\text { Strategynegotiatio } \\
\mathrm{n} \quad \text { Witholding sex }\end{array}$ & 1.4 & 0.5 & 0.54 & 3.61 \\
$\quad$ Direct request & 2.1 & 0.12 & 0.82 & 5.68 \\
$\quad$ Deception & 2.5 & 0.035 & 106 & 5.62 \\
$\begin{array}{l}\text { Availability of } \\
\text { condoms }\end{array}$ & 13.7 & $<0.0001$ & 4.45 & 42.2 \\
$\begin{array}{l}\text { Age } \leq 38 \text { years } \\
\text { Knowledge of }\end{array}$ & 10.6 & 0.002 & 2.4 & 47.3 \\
$\begin{array}{l}\text { STDs } \\
\text { Perceived }\end{array}$ & 2.2 & 0.28 & 0.5 & 9.1 \\
susceptibility & 1.4 & 0.5 & 0.44 & 4.72 \\
\hline
\end{tabular}

The consistently of condoms use is generally measured by assessing the use of condoms by consistent within one week, the proportion obtained was $63 \%$. This is consistent with research in Semarang on the consistency of condom use. Only $56.3 \%$ consistent use of condoms [8]. Consistent results were also mentioned in the report Behavioral Biology
Integrated Surveying (IBBS) in 2011 that the consistent use of condoms only $14 \%$ [4].

The most effective strategy to increase consistent condom use is deceptive to the customers (AOR: 2.5 95\% CI: 1.06 to 5.62). The sex workers are pursuing a strategy of negotiation with the customer lying to 2.5 times increase customers to use condoms during sexual intercourse. A deceptive strategy is an effective strategy and valid as the solicitation of sex workers to the partner/customers to use condoms [6]. Deception was reportedly used by $35 \%$ of men and women in affecting couples to use condoms. The strategy is made by lying to customers so that customers use condoms consistently [9]. Measurement of negotiation strategies through this deceptive is an adaptation of the questionnaire CISQ way to tell the customer that the use of condoms to prevent pregnancy even though in fact to prevent STDs. Another strategy to explain to the customer that all customers use when not all customers want to use condoms [6].

Except of the condom negotiation strategies, other related variables were age $\leq 35$ years WPS (young). Age is one of the internal factors that influence a behavior. Direct sex workers when younger age appears significantly associated with condom use and 4.8 times higher than the old sex workers (OR: $4.8 ; 95 \%$ CI 3.1 to 7.5) [10]. Research in Vietnam also getting the younger of sex workers consistent in the use of condoms to customers [11]. Woman sex workers are less open to change in terms of behavior, so behavior condom use is not consistent settling and unchanged [12].

The availability of condoms in the location is also a variable that relates to the consistency of condom. Research in the Philippines also shows the same thing about the availability of condoms with condom use [13]. The same results were consistent and were also found in the study in Indonesia [14], India [15], Republic of Congo [16], Ghana [10] that the availability of condoms in locations associated with the consistent use of condoms. Other research results in Indonesia also showed the same results that the availability of condoms has a significant relationship with the practice of the use of condoms [17].

\section{CONCLUSIONS}

Condom negotiation strategies are most effective for improving the consistency of condom use on customers is to deceive customers. Variables associated with consistent condom use is the age of sexworkers who are young and availability of condoms at the location. 


\section{REFERENCES}

[1] UNAIDS. Global AIDS Response Progress Reporting 2015.

[2] Ruxrungtham K, Brown T, Phanuphak P. HIV / AIDS in Asia. Lancet. 2004, 364: 69.

[3] Ministry of Health. 2012 Size Estimation of Key Affected Populations (KAPS). 2012.

[4] The Ministry of Health DG P2PL. IBBS 2011 (Integrated Biological and Behavioral Surveillance). 2011.

[5] Wirawan D. et al. Trends in HIV Prevalence, Condom Use and Associated Factors among Female Sex Workers in Denpasar, Bali, Indonesia. Prev Med Public Heal Arch. 2014; II.

[6] Noar BC, Morokoff PJ, Harlow LL. Condom Negotiation in Heterosexually Active Men and Women: Development and Validation of a Condom Influence Strategy Questionnaire. Health Psychol. 2002, 17 No. 6: 711-35.

[7] Bui TC, Markaham CM, Tran LT., Beasley RP, Ross MW. Negotiation and Condom Use Among Female Sex Workers in Phnom Penh, Cambodia. AIDS Behav. 2013, 17: 612-22.

[8] Irwan B. Consistency of Condom Use by Women Sex Workers / Consumers.J Kesehatmobi. 2012, II.

[9] DEBRO S., Campbell S., L. Peplau Influencing a Partner to Use Condom: a College Student Perspective. Woman Physicology Q. 1994, 16582.
[10]. AOppongAdu et al. Social Behavioral Determinants of Condom Use Among Female Commercial Sex Workers in Ghana. AIDS Educ Prev. 2007, 160.

[11] Tran T. et al. Condom Use and Its Correlates Among Female Sex Workers in Hanoi, Vietnam. Behavio AIDS.2006; 10 No 2.

[12] Atif $\mathrm{M}$ et al. Prevalence of Condom Use and Associated Factor s Among Female Sex Workers In Karachi, Pakistan. Int J Cur Res. 2015, 7 No. 2.

[13] Urada LA, Morisky DE, Pimentel-Simbulan N, Silverman JG, Strathdee SA. Negotiations Condom among Female Sex Workers in the Philippines: Environmental Influence. PLoS One. 2012, 7 (3).

[14] Basuki E et al. Reason For Not Using Condoms Among Female Sex Workers in Indonesia. AIDS Educ Prev. 2002, 14, No. 2: 102-16.

[15] Dandona R et al. High Risk of HIV in NonBrothel Based Female Sex Workers in India. BMC Public Health. 2005, 5: 87.

[16] Kayembe, PK, Mapatano, MA, Busangu, AF, Nyandwe, JK, Musema, GM, Kibungu JP. Determinant of Consistent Condom Use Among Female Sex Workers in the Democratic Republic of Congo: Implication for Sexually Transmitted Infection Intervention. 2008, 84 No 3: 202-6.

[17] Hadi TS. Factors Affecting the Practice Negotiating condom to prevent STIs and HIV / AIDS at the WPS in ResocializationArgorejo Semarang.Diponegoro University, 2004. 